\title{
Midwifery Care for Postpartum Mothers and Breastfeeding for Mrs. N In Dealing With Breast Milk is not yet Smooth
}

\author{
Wilda Nudelis ${ }^{1}$, Diah Atmarina Yuliani ${ }^{2}$ \\ ${ }^{1,2}$ Program Studi Kebidanan DIII, Universitas Muhammadiyah Purwokerto
}

\begin{abstract}
ARTICLE INFO
Article history:

DOI:

10.30595/pshms.v2i.224

Submitted:

December 6, 2021

Accepted:

January 21, 2022

Published:

January 26, 2022

Keywords:

Breast Milk; Katuk Leaves; Breastfeeding Mothers

ABSTRACT

The postpartum period starts from 2 hours after the birth of the placenta until 6 weeks (42 days) after that. Puerperium is a period of recovery, starting from the completion of labor until the uterine devices return to their original state as before pregnancy. Katuk leaves contain compounds that can stimulate the hormone prolactin so that breast milk increases. One of the efforts to increase breast milk is to improve the quality of foods that have a direct effect on milk production, such as green vegetables, katuk leaves, sweet potato leaves, papaya leaves and so on. Katuk leaves contain almost $7 \%$ protein and $19 \%$ crude fiber, vitamin $\mathrm{K}$, pro-vitamin A (beta-carotene, vitamins $\mathrm{B}$ and $\mathrm{C}$. The minerals contained are calcium (2.8\%) iron, potassium, phosphorus and magnesium. To find out the application of consuming katuk leaves can launch Mother's Milk. This scientific paper uses a method, namely a case study report using a descriptive method, the location at the residence of Mrs. N Gintung Agung Village, Lambur RT 03 RW 01 Kec. Mrebet Purbalingga Regency. The subject of the case study was the 5th day postpartum mother, namely Mrs. $\mathrm{N}$ with a little milk. The case study time is on March 23, 2021. Data collection techniques include interviews and secondary studies including documentation and literature studies. Mother's general condition was good, after consuming katuk leaves, Mother's Milk (ASI) increased. Giving katuk leaves is effective to increase breast milk for nursing mothers.
\end{abstract}

This work is licensed under a Creative Commons Attribution 4.0 International License.

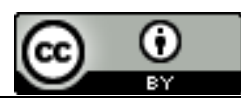

\section{Corresponding Author:}

Wilda Nudelis,

Department of Health, Muhammadiyah University of Purwokerto,

Soepardjo Rustam Street KM. 7, Banyumas, Indonesia

Email: wildauser7@gmail.com

\section{INTRODUCTION}

The postpartum period begins 2 hours after the birth of the placenta until 6 weeks (42 days) after that. Puerperium is a period of recovery, starting from the completion of labor until the uterine devices return to their original state as before pregnancy. Many problems that arise during this postpartum period, one of which is very little milk production. Exclusive breastfeeding is a baby who is only breastfed, from the age of 30 minutes postnatal until the age of 6 months without any addition. One way to increase breast milk production is by consuming katuk leaf extract. Katuk leaves contain compounds that can stimulate the hormone prolactin so that breast milk increases. [1]

Exclusive breastfeeding is one of the global strategies to improve infant growth, development, health and survival. Breast milk provides all of the nutritional and energy requirements for the first month, half or more of the nutrients during the second 6 months of the first year, and 1/3 or more during the second year. Breast milk also contains protective substances that can prevent babies from various diseases. [2]

Breastfeeding according to the baby's needs means benefits for all, the baby will be healthier, smarter and have a good personality, the mother will be healthier and more attractive. Companies, the environment, and the community will also benefit more. Breastfeeding is very important to improve our human resources in the future, especially in terms of nutritional adequacy from an early age. [3] 
One of the efforts to increase breast milk is to improve the quality of foods that have a direct effect on milk production, such as green vegetables, katuk leaves, sweet potato leaves, papaya leaves and so on. Katuk leaves contain almost $7 \%$ protein and $19 \%$ crude fiber, vitamin K, pro-vitamin A (beta-carotene, vitamins $\mathrm{B}$ and $\mathrm{C}$. The minerals contained are calcium (2.8\%) iron, potassium, phosphorus and magnesium. [4]

\section{RESEARCH METHOD}

This scientific paper uses a method, namely a case study report using a descriptive method, the location at the residence of Mrs. N Gintung Agung Village, Lambur RT 03 RW 01 Kec. Mrebet Purbalingga Regency. The subject of the case study was the 5th day postpartum mother, namely Mrs. N with a little milk. The case study time is on March 23, 2021. Data collection techniques include interviews and secondary studies including documentation and literature studies.

\section{RESULT AND DISCUSSIONS}

In the assessment of midwifery care in postpartum mothers with little breast milk, it was carried out by collecting basic data, namely based on the 5th day postpartum with little breast milk and using katuk leaves. Subjective data is the mother said her milk came out a little. Objective data obtained from patient data are good general condition, composmentis awareness, blood pressure: 110/70 $\mathrm{mmHg}$, pulse: $82 \mathrm{x} / \mathrm{minute}$, respiration: $21 \mathrm{x} /$ minute, temperature $36.5^{\circ} \mathrm{c}$, weight: $63 \mathrm{Kg}$, eyes: red conjunctiva young, white scelra, breast: symmetrical, no lump, colostrum has come out, milk has come out a little, abdomen decreased uterine fundus 4 lower center finger, hard contractions, empty bladder, genetalia: no edema, lochea rubra, stitches look clean but not yet dry, no pus and no odor, extremities: no varices or edema.

Based on the data above, there is no gap between theory and on the ground, Mrs. N's case was not found to be an emergency, so no immediate treatment was carried out. So that there is no gap between theory and on the ground.

\section{CONCLUSION}

Based on the discussion that the author got in the case management of Mrs. N's baby with little breast milk in Gintung Agung Village, Lambur RT 03 RW 01 Kec. Mrebet Purbalingga Regency uses midwifery management according to Varney with the SOAP documentation method, the authors conclude the following:

From the assessment that the author got from midwifery care for postpartum mothers with little breast milk, it was carried out by collecting basic data, namely based on Mrs. N postpartum on day 5 with little breast milk and using katuk leaves. Subjective data is the mother said her milk came out a little. Objective data obtained from patient data are good general condition, composmentis awareness, blood pressure: $110 / 70 \mathrm{mmHg}$, pulse: $82 \mathrm{x} /$ minute, respiration: $21 \mathrm{x} /$ minute, temperature $36.5^{\circ} \mathrm{c}$, weight: $63 \mathrm{Kg}$, eyes: red conjunctiva young, white scelra, breast: symmetrical, no lump, colostrum has come out, milk has come out a little, abdomen decreased uterine fundus 4 lower center finger, hard contractions, empty bladder, genetalia: no edema, lochea rubra, stitches look clean but not yet dry, no pus and no odor, extremities: no varices or edema.

From the subjective and objective data that have been obtained, the diagnosis can be drawn, namely the 36-year-old baby Mrs. N with little breast milk. For the management of the diagnosis, namely explaining the results of the examinations that have been carried out, informing Mrs. $\mathrm{N}$ the results of the examination and explaining the current situation, advises the mother not to worry about the condition of the mother whose breast milk comes out a little. In addition, it is recommended for mothers to consume katuk leaves so that breast milk is smooth and katuk leaves as a food menu to increase the adequacy of breast milk.

\section{Acknowledgements}

Thank you to Allah SWT, both parents and all comrades in arms who have helped from beginning to end.

\section{REFERENCES}

[1] Abiyoga, "Faktor-faktor Yang Berhubungan Dengan Kejadian Gout Pada Lansia Di Wilayah Kerja Puskesmas Situraja Tahun 2014," Jurnal Darul Azhar, vol. 2, no. 1, p. 47-56, 2017.

[2] M. Katuuk, "Hubungan Kemunduran Fisiologis Dengan Tingkat Stres Pada Lanjut Usia Di Puskesmas Kakaskasen Kecamatan Tomohon Utara,” Jurnal Keperawatan, vol. 6, no. 1, 2018.

[3] Risdianto, "Hubungan Dukungan Sosial dengan Kualitas Hidup Lanjut Usia di Desa Kembang Kuning Cepogo Boyolali.," Skripsi Fakultas Ilmu Kesehatan Universitas Muhammadiyah Surakarta, tidak dipublikasikan, Surakarta, 2009. 
[4] Nugroho, Keperawatan Gerontik \& Geriatrik, 3 penyunt., Jakarta: EGC, 2008.

[5] S. Rohaedi et al., "Tingkat Kemandirian Lansia Dalam Activities Daily," Pendidikan Keperawatan Indonesia, vol. 2, no. 1, p. 17, 2016. 